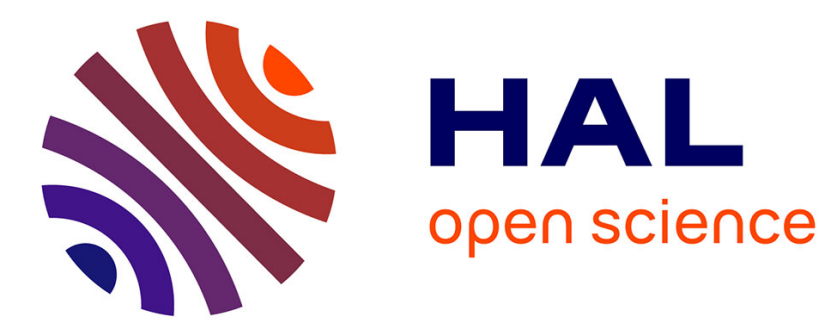

\title{
Plasma cortisol levels of female rainbow trout (Salmo gairdneri) at the end of the reproductive cycle: Relationship with oocyte stages
}

\author{
Christian Bry
}

\section{To cite this version:}

Christian Bry. Plasma cortisol levels of female rainbow trout (Salmo gairdneri) at the end of the reproductive cycle: Relationship with oocyte stages. General and Comparative Endocrinology, 1985, 57 (1), pp.47-52. 10.1016/0016-6480(85)90199-6 . hal-01608553

\section{HAL Id: hal-01608553 \\ https://hal.science/hal-01608553}

Submitted on 2 Jun 2020

HAL is a multi-disciplinary open access archive for the deposit and dissemination of scientific research documents, whether they are published or not. The documents may come from teaching and research institutions in France or abroad, or from public or private research centers.
L'archive ouverte pluridisciplinaire HAL, est destinée au dépôt et à la diffusion de documents scientifiques de niveau recherche, publiés ou non, émanant des établissements d'enseignement et de recherche français ou étrangers, des laboratoires publics ou privés.

\section{다(1)(2)}

Distributed under a Creative Commons Attribution - ShareAlikel 4.0 International 


\title{
Plasma Cortisol Levels of Female Rainbow Trout (Salmo gairdneri) at the End of the Reproductive Cycle: Relationship with Oocyte Stages
}

\author{
C. BRY \\ Laboratoire de Physiologie des Poissons, INRA 78350-Jouy-en-Josas, France
}

Accepted March 6, 1984

\begin{abstract}
The concentrations of plasma cortisol were determined in two populations of female rainbow trout at the end of their reproductive cycles. In females ending vitellogenesis or having oocytes with germinal vesicles in peripheral positions, mean cortisol levels were low (about 8 to $10 \mathrm{ng} / \mathrm{ml}$ ). Cortisol concentrations remained low during oocyte maturation (about 8 and $11 \mathrm{ng} / \mathrm{ml}$ ). In contrast, a 3 -fold cortisol increase was observed in females sampled in the postovulation period (about 26 and $31 \mathrm{ng} / \mathrm{ml}$ ). These results are discussed in relation to other studies on endocrinological changes during the spawning season with emphasis on the possible role of cortisol in reproduction in female teleosts. 1985 Academic Press, Inc.
\end{abstract}

Seasonal elevations of plasma cortisol or corticosteroid levels during the spawning period have been reported in a number of female teleost fishes: migratory Salmonidae (e.g., Hane and Robertson, 1959; Idler et al., 1959; Schmidt and Idler, 1962; Fagerlund and Donaldson, 1970; Heyl and Carpenter, 1972); a landlocked salmonid fish, Coregonus lavaretus (Fuller et al., 1976); nonmigratory rainbow trout, Salmo gairdneri (Robertson et al., 1961) and hatcheryreared brown trout, Salmo trutta (Pickering and Christie, 1981); the plaice, Pleuronectes platessa (Wingfield and Grimm, 1977); and the goldfish, Carassius auratus (Cook et al., 1980). Despite such apparently converging evidence, no clear pattern has yet emerged with regard to the stages of the maturation-ovulation-oviposition sequence effectively associated with an increase in the corticosteroid hormone. In the goldfish, for example, a surge in serum cortisol was found a few hours prior to ovulation and cortisol levels declined at the time of ovulation and thereafter (Cook et al., 1980). In contrast, brown trout sampled in the postovulation period had elevated cortisol concentrations (Pickering and
Christie, 1981) and in C. lavaretus the highest cortisol levels during the spawning season were recorded in ovulated females caught on the spawning grounds (Fuller et al., 1976). On the other hand, in vitro experiments with rainbow trout follicles suggest that some corticosteroids might play an indirect role in oocyte maturation by lowering the threshold of oocyte sensitivity to the maturation-inducing factor (Jalabert, 1975, 1976).

The present investigation was accordingly undertaken in an attempt to establish with precision the temporal links between circulating cortisol levels and the final stages of ovarian evolution in the rainbow trout. Based on macroscopic modifications of the oocytes, several preovulation stages have been defined in the trout (Jalabert et al., 1976) and related with the levels of reproductive hormones (e.g., Fostier et al., 1978). Another advantage of the trout model when compared with fish reproducing in warmer waters is the relatively long duration of oocyte maturation (Jalabert, 1978; Bry, 1981), a feature which may allow a more accurate description of temporal relationships. 
In addition, the choice of a hatcheryreared species offers the possibility of reducing the time interval between capture and sampling to a minimum compatible with the measurement of normal (i.e., not influenced by handling) cortisol levels.

\section{MATERIALS AND METHODS}

Experimental conditions. Two similar experiments were carried out in October-November 1979 and November-December 1982. Forty-eight and sixty female rainbow trout $(S$. gairdneri Richardson; weight range $900-1700 \mathrm{~g}$ ) were used, respectively. These females were in their third year and at the end of their second reproductive cycle. The 1979 trout originated from a commercial trout hatchery, whereas the 1982 fish belonged to a population raised by our geneticist colleagues and characterized by a high level of overall genetic variability. For $5-7$ weeks before the start of the sampling period the fish were acclimated to outdoor circular tanks (600 liters) spaced away from each other, supplied with running river water (flow rate 40 liters/min, trout stocking density $30 \mathrm{~kg} / \mathrm{m}^{3}$, or $0.5 \mathrm{~kg} /$ liter per min) and fed once a day between 0900 and $0930 \mathrm{hr}$ with dry pellets ( $1 \%$ body wt/day). As no fungal infection was observed in the experimental fish, no sanitary treatment was performed. Water temperature range was $8.5-10.5^{\circ}$ during the 1979 and 1982 sampling periods.

Sampling protocol. On sampling days the fish were fed as usual and care was taken to avoid activity in the vicinity of the experimental tanks. Between 1230 and $1300 \mathrm{hr}$ one fish was quickly removed from each tank and immobilized. A blood sample was withdrawn with a heparinized syringe from the dorsal aorta within $30-50 \mathrm{sec}$ of introducing the hand net into the tank. This time interval is well within the few minutes lag that takes place before cortisol levels begin to rise in rainbow trout captured and left struggling out of water (Bry, unpublished data). On some occasions, two fish were taken together from each tank, but the aforementioned timing was respected. There was an interval of $1-2$ days in 1979 and 3-10 days in 1982 between two successive sampling dates. Once sampled for blood, each female was anesthetized in a 2-phenoxyethanol solution $(0.3 \mathrm{ml} /$ liter $)$ and several oocytes were collected by abdominal stripping. The stage of oocyte development was determined under a binocular microscope according to the following classification (adapted from Jalabert et al., 1976):

1: Immature oocyte with migrating germinal vesicle (G.V.). Oocytes having a G.V. in subperipheral position were included in this category.

2: Immature oocyte with peripheral G.V.

3: Maturing oocyte. In most cases these oocytes were in a relatively advanced state of maturation, i.e., at or after G.V. breakdown time.

4: Matured and ovulated oocyte.

Following blood and oocyte sampling, the fish were not returned to the experimental tanks. In 1982 the nonovulated females were put aside after sampling and checked twice a week in order to estimate the time lag between sampling and ovulation.

Ovulated females were first detected on October 30 , 1979 (second sampling session) and on December 6, 1982 (third sampling session). In 1982, 2 weeks elapsed between the first detection of ovulated females and the date of the last sampling. Half of the population was estimated as ovulated by November 7, 1979, and by December 14, 1982.

Cortisol assay. Each plasma sample $(0.2 \mathrm{ml})$ was assayed in triplicate for cortisol, using a competitive protein binding assay systematically preceded by a chromatographic step (Sephadex LH-20) as previously described (Bry and Zohar, 1980). This procedure removed potentially interfering steroids such as progesterone, $17 \alpha$-hydroxyprogesterone, 11-deoxycortisol, and cortisone. The assay showed a negligible crossreactivity with $17 \alpha$-hydroxy-20 3 -dihydroprogesterone, a progestagen which is elevated at the time of oocyte maturation and ovulation in the rainbow trout (Fostier et al., 1981; Scott et al., 1983). In our working conditions, the detection limit was close to $1 \mathrm{ng} / \mathrm{ml}$. The coefficients of variation were below $6 \%$ (within assay) and below $13 \%$ (between assays) for plasma cortisol concentrations between 5 and $25 \mathrm{ng} / \mathrm{ml}$.

Statistical analyses. The cortisol data were logarithmically transformed in order to meet variance homogeneity and subjected to a two-way analysis of variance with oocyte stage and year of experiment as factors. When the $F$ value for a given parameter was significant, the data were further analysed using Kramer's (1956) modification of Newman-Keuls multiple range test.

\section{RESULTS}

Cortisol levels exhibited significant variations with respect to ovarian stages at the time of sampling (Fig. $1, P<0.005$ ) and the patterns of cortisol changes observed in the 1979 and 1982 rainbow trout populations were not significantly different $(P>0.05)$. In females having oocytes with a migrating or peripheral G.V. (stages 1 and 2) as well as in maturing females (stage 3 ), the mean concentrations of circulating cortisol were low and ranged from 7.7 to $10.5 \mathrm{ng} / \mathrm{ml}$, with no significant difference according to oocyte stage $(P>0.05)$. In contrast, a 


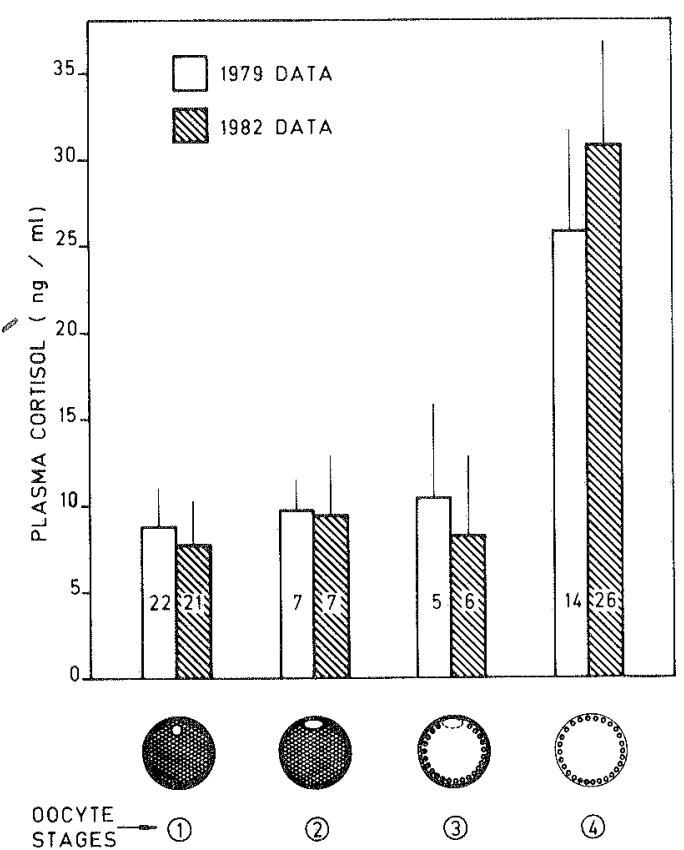

FIG. 1. Plasma cortisol concentrations (arithmetic mean + SEM) of female rainbow trout at the end of the reproductive cycle, in relation to oocyte stages. The experiment was conducted in October-November 1979 and replicated in November-December 1982. The numbers of fish in each category are indicated inside the vertical bars. The stages of oocyte maturation are classified as follows: (1) immature oocyte with migrating germinal vesicle (G.V.); (2) immature oocyte with peripheral G.V.; (3) maturing oocyte (see details under Materials and Methods); (4) matured and ovulated oocyte. The levels of plasma cortisol at stage 4 (postovulation) are significantly different from the values associated with stages $1,2,3(P$ $<0.01$, derived from analysis of variance on log-transformed data).

three-fóld elevation of cortisol levels was observed in females sampled postovulation (stage 4; mean values: 25.8 and $30.9 \mathrm{ng} / \mathrm{ml}$ ). In the 1982 trout population, no significant difference in cortisol titers was found between ovulated females sampled at the beginning of the population ovulation period and ovulated females sampled $10-15$ days later $(31.8$ and $26.8 \mathrm{ng} / \mathrm{ml}$, respectively; $P$ $>0.05)$. The average time interval between the sampling date of a female at a defined ovarian state and the date of ovulation was
35 days for stage 1,8 days for stage 2 , and 3 days for stage 3 .

\section{DISCUSSION}

The results of our investigation indicate a marked elevation of plasma cortisol levels in the female rainbow trout during the postovulation period, in comparison with the low cortisol concentrations observed during several preovulatory stages. The timing of this cortisol increase is not known, due to the strict requirements of our sampling protocol which precluded handling of the fish at any time before the sampling date and therefore did not permit us to record the ovulation dates for the females sampled postovulation. It appears probable, however, that cortisol elevation lasts some time, since cortisol levels were similarly elevated in ovulated females sampled at the beginning of the population ovulation period and in ovulated females sampled 10-15 days later (in the latter lot, the average time interval between ovulation and sampling being presumably longer). Our results are consistent with the findings of Pickering and Christie (1981) who reported a 4 -fold difference in cortisol levels between nonovulated and ovulated female brown trout $(13.5 \mathrm{ng} / \mathrm{ml}$ and $53.1 \mathrm{ng} / \mathrm{ml}$, respectively). In contrast, serum cortisol levels of ovulatory and nonovulatory female goldfish did not differ at the time of ovulation or after ovulation, although a peak in serum cortisol was found in the ovulatory fish group 4-8 hr prior to ovulation (Cook et al., 1980). At present, we can only speculate on the biological significance of a cortisol increase in ovulated trout. Cortisol might be involved in the control of ovulation sensu stricto (i.e., the expulsion of the mature oocyte from the follicle). In this respect, Hirose and Ishida (1974) have shown that high dosages of cortisol administered to ayu (Plecoglossus altivelis) could induce hydration of the oocytes and ovulation. On the other hand, cortisol might play a role in spawning be- 
havior. In connection with the latter hypothesis, it may be noted that a rise in corticosterone, peaking at the time of oviposition, was demonstrated in laying hens (Beuving and Vonder, 1981). Interestingly, the plasma concentrations of several other hormones are elevated for prolonged periods of time after spontaneous ovulation in some salmonids; glycoproteic gonadotrophin (Jalabert and Breton, 1980; Scott et al., 1983) and 17 $\alpha$-hydroxy-20 $\beta$-dihydroprogesterone (Fostier et al., 1981; Scott et al., 1983) in the rainbow trout; prostaglandins in the brook trout (Goetz and Cetta, 1983). It should be emphasized, however, that the situation of ovulated trout in most endocrinological studies (including the present study) is necessarily somewhat artificial, since spawning behavior does not usually take place in captive female trout under conditions of intensive rearing in tanks. A better understanding of the possible involvement of cortisol (and other hormones) in the oviposition of female trout will obviously require work on fish undergoing the complete spawning sequence in a seminatural environment.

Another possible interpretation of our results is that the extended presence of ova and associated fluid within the body cavity might induce a state of moderate ill-being, resulting in an increased cortisol secretion. Histological studies on female rainbow trout in possession of overripened ova ( $\mathrm{sev}$ m eral weeks after ovulation) showed degenerative changes in hepatic and urinary tissues and a hyperfunctional state in the interrenal gland (Takashima et al., 1975). Additional studies on the kinetics of cortisol elevation in ovulated trout and on the general behavior of these fish would help to clarify this issue.

On the basis of the results of the present study, it appears that there is no elevation of plasma cortisol in female rainbow trout during oocyte maturation at or after G.V. breakdown time. This result does not rule out the possibility of a short-lived cortisol increase at the time of natural, maturationinducing gonadotrophin release (oocyte with peripheral G.V., shortly before the initiation of macroscopic modifications) and/ or at the very beginning of oocyte maturation (maturing oocyte before G.V. breakdown). This hypothesis would be difficult to test, however, due to the transient nature of such stages and to the impossibility of handling the fish and sampling oocytes repeatedly, if a valid measurement of cortisol levels at rest is to be made.

The cortisol concentrations observed in preovulatory rainbow trout (this study: stages $1,2,3$; about 8 to $11 \mathrm{ng} / \mathrm{ml}$ ) are comparable to the daily means found in JuneJuly in catheterized female rainbow trout (about 5 to $10 \mathrm{ng} / \mathrm{ml}$; Bry, 1982) and are among the lowest values reported in nonovulated salmonid fish during the reproductive period. The notable differences in cortisol levels between various studies of sal monid fish during reproduction may be attributed to differences in species or in situations (wild migrating fish vs hatcheryreared fish). These discrepancies may also result from a lack of methodological standardization concerning: (1) in the case of a domesticated species, the conditions of acclimatization to the experimental environment (for an illustration of the importance of stocking density, see Pickering and Pottinger, 1983); (2) the time interval between capture and blood sampling; and (3) the specificity of cortisol assay.

\section{REFERENCES}

Beuving, G., and Vonder, G. M. A. (1981). The influence of ovulation and oviposition on corticosterone levels in the plasma of laying hens. Gen. Comp. Endocrinol. 44, 382-388.

Bry, C. (1981). Temporal aspects of macroscopic changes in rainbow trout (Salmo gairdneri) oocytes before ovulation and of ova fertility during the post-ovulation period: Effect of treatment 
with $17 \alpha$-hydroxy-20 $\beta$-dihydroprogesterone. Aquaculture 24, 153-160.

Bry, C. (1982). Daily variations in plasma cortisol levels of individual female rainbow trout Salmo gairdneri: Evidence for a post-feeding peak in well-adapted fish. Gen. Comp. Endocrinol. 48, $462-468$.

Bry, C., and Zohar, Y. (1980). Dorsal aorta catheterization in rainbow trout (Salmo gairdneri). II. Glucocorticoid levels, hematological data and resumption of feeding for five days after surgery. Reprod. Nutr. Dev. 20, 1825-1834.

Cook, A. F., Stacey, N. E., and Peter, R. E. (1980). Periovulatory changes in serum cortisol levels in the goldfish, Carassius auratus. Gen. Comp. Endocrinol. 40, 507-510.

Fagerlund, U. H. M., and Donaldson, E. M. (1970). Dynamics of cortisone secretion in sockeye salmon (Oncorhynchus nerka) during sexual maturation and after gonadectomy. J. Fish. Res. Board Canad. 27, 2323-2331.

Fostier, A., Weil, C., Terqui, M., Breton, B., and Jalabert, B. (1978). Plasma oestradiol- 173 and gonadotropin during ovulation in rainbow trout (Salmo gairdneri R.). Ann. Biol. Anim., Biochim., Biophys. 18, 929-936.

Fostier, A., Breton, B., Jalabert, B., and Marcuzzi, O. (1981). Evolution des niveaux plasmatiques de la gonadotropine glycoprotéique et de la $17 \alpha$-hydroxy-20ß-dihydroprogestérone au cours de la maturation et de l'ovulation chez la Truite arc-enciel, Salmo gairdneri. C. R. Hebd. Seances Acad. Sci., Ser. $D$ 293, 8,17-820.

Fuller, J. D., Scott, D. B. C., and Fraser, R. (1976). The reproductive cycle of Coregonus lavaretus (L) in Loch Lomond, Scotland, in relation to seasonal changes in plasma cortisol concentration. $J$. Fish Biol. 9, 105-117.

Goetz, F. W., and Cetta, F. (1983). Ovarian and plasma PGE and PGF levels in naturally ovulating brook trout (Salvelinus fontinalis) and the effects of indomethacin on prostaglandin levels. Prostaglandins 26, 387-395.

Hane, S., and Robertson, O. H. (1959). Changes in plasma 17-hydroxycorticosteroids accompanying sexual maturation and spawning of the Pacific salmon (Oncorhynchus tshawytscha) and rainbow trout (Salmo gairdneri). Proc. Natl. Acad. Sci. USA 45, 886-893.

Heyl, H. L., and Carpenter, S. J. (1972). Reversible changes in adrenal cortical cell morphology and plasma hydroxycorticosteroids during freshwater portion of the spawning journey of Atlantic salmon (Salmo salar). J. Fish. Res. Board Canad. $29,311-314$.

Hirose, K., and Ishida, R. (1974). Effects of cortisol and human chorionic gonadotrophin ( $\mathrm{HCG}$ ) on ovulation in ayu Plecoglossus altivelis (Temminck and Schlegel) with special respect to water and ion balance. J. Fish Biol. 6, 557-564.

Idler, D. R., Ronald, A. P., and Schmidt, P. J. (1959). Biochemical studies on sockeye salmon during spawning migration. VII. Steroid hormones in plasma. Canad. J. Biochem. Physiol. 37, 12271238.

Jalabert, B. (1975). Modulation par différents stéroïdes non maturants de l'efficacité de la $17 \alpha$-hydroxy$20 \beta$-dihydroprogestérone ou d'un extrait gonadotrope sur la maturation intrafolliculaire in vitro des ovocytes de la Truite arc-en-ciel Salmo gairdneri. C. R. Hebd. Seances Acad. Sci., Ser. D 281, $811-814$.

Jalabert, B. (1976). In vitro oocyte maturation and ovulation in rainbow trout (Salmo gairdneri), northern pike (Esox lucius), and goldfish (Carassius auratus). J. Fish. Res. Board Canad. 33, 974-988.

Jalabert, B. (1978). Production of fertilizable oocytes from follicles of rainbow trout (Salmo gairdneri) following in vitro maturation and ovulation. Ann. Biol. Anim., Biochim., Biophys. 18, 461-470.

Jalabert, B., and Breton, B. (1980). Evolution de la gonadotropine plasmatique t-GTH après l'ovulation chez la Truite arc-en-ciel (Salmo gairdneri $R$ ) et influence de la rétention des ovules. $C . R$ Hebd. Seances Acad. Sci., Ser. D 290, 799-801.

Jalabert, B., Bry, C., Breton, B., and Campbell, C., (1976). Action de la $17 \alpha$-hydroxy-20ß-dihydroprogestérone et de la progestérone sur la maturation et l'ovulation in vivo et sur le niveau d'hormone gonadotrope plasmatique t-GTH chez la truite arc-en-ciel Salmo gairdneri. C. R. Hebd. Seances Acad. Sci., Ser, D 283, 1205-1208.

Kramer, C. Y. (1956). Extension of multiple range tests to group means with unequal numbers of replications. Biometrics 12, 307-310.

Pickering, A. D., and Christie, P. (1981). Changes in the concentrations of plasma cortisol and thyroxine during sexual maturation of the hatcheryreared brown trout, Salmo trutta L. Gen. Comp. Endocrinol. 44, 487-496.

Pickering, A. D., and Pottinger, T. G. (1983). Seasonal and diel changes in plasma cortisol levels of the brown trout, Salmo trutta L. Gen. Comp. Endocrinol. 49, 232-239.

Robertson, O. H., Krupp, M. A., Thomas, S. F., Favour, C. B., Hane, S., and Wexler, B. C. (1961). Hyperadrenocorticism in spawning, migratory, and non-migratory rainbow trout (Salmo gairdneri): Comparison with Pacific salmon (genus $\mathrm{On}^{-}$ corhynchus). Gen. Comp. Endocrinol. 1, 473484.

Schmidt, P. J., and Idler, D. R. (1962). Steroid hormones in the plasma of salmon at various states 
of maturation. Gen. Comp. Endocrinol. 2, 204-214.

Scott, A. P., Sumpter, J. P., and Hardiman, P. A. (1983). Hormone changes during ovulation in the rainbow trout (Salmo gairdneri R.). Gen. Comp. Endocrinol. 49, 128-134.

Takashima, F., Nomura, M., and Sakai, K. (1975). The over-ripening phenomenon of rainbow trout. III. Histological studies on the physiological condition of overripened female. Bull. Japan. Soc. Sci. Fish. 41, 861-867.

Wingfield, J. C., and Grimm, A. S. (1977). Seasonal changes in plasma cortisol, testosterone, and oestradiol-17 7 in the plaice, Pleuronectes platessa L. Gen. Comp. Endocrinol. 31, 1-11. 